\title{
THE SPECIES OF HIPPOLYTE LEACH (CRUSTACEA, CARIDEA, HIPPOLYTIDAE) FROM TERMINOS LAGOON, SOUTHWESTERN GULF OF MEXICO
}

\author{
M.L. Negreiros-Fransozo ${ }^{1}$ \\ E. Barba ${ }^{2}$ \\ A.J. Sanchez ${ }^{2}$ \\ A. Fransozo 1 \\ A. Ráz-Guzmán ${ }^{2}$
}

\begin{abstract}
The taxonomic identity of specimens of the genus Hippolyte Leach, 1814 of Laguna de Términos was considered including the colour and the presenceabsence of tufts of plumose setae on the dorsal surface of the carapace and abdomen as secondary characteristics to morphological features of taxonomic value. Two groups were formed based on appearance: one transparent with setae and another green without setae. The analysis of five morphological characteristics in adult females of the two groups made it possible to identify only $H$. zostericola (Smith, 1873). Fecundity and fertility were similar $(0.5>p>0.2)$ in both groups. The first zoea of both groups were also morphologically similar. Considering these results, it is concluded that the only species collected was $H$. zostericola and that it has two phenotypical types. It is recomended that the morphological analysis of all larval stages be carried out.
\end{abstract}

KEY WORDS. Hippolyte, zoea, fertility, fecundity, SW Gulf of Mexico

The crustaceans associated with aquatic vegetation in the four greatest lagoon systems in the southwestern Gulf of Mexico include the carideans among the most abundant components (BARBA et al. 1993). Among these, at least one species of the family Hippolytidae is a dominant component in the two biggest coastal lagoons of this region, Laguna Madre in Tamaulipas and Laguna de Términos in Campeche (BARBA et al. 1993)

In the case of Laguna de Términos, Hippolyte zostericola has been registered as dominant among the 15 species of carideans of the northcentral-northeastern region of the lagoon (LEDOYER 1986; BARBA et al. 1993). This is meaningful as the greatest densities of carcinofauna (RÁz-GUZMAN et al. 1986; SÁNCHEZ \& RÁzGUZMÁN 1992; SÁNCHEZ 1994), seagrasses (DAY et al. 1982), red algae and sponges are found in this area. The dominance of this species has been registered with respect to density and biomass, and persists over circadian, seasonal and interannual scales of time (BARBA et al. 1993).

1) Departamento de Zoologia, Instituto de Biociências e Centro de Aqüicultura, Universidade Estadual Paulista. 18618-000 Botucatu, São Paulo, Brasil.

2) Laboratorio Ecologia del Bentos, Instituto de Ciencias del Mar y Limnologia, Universidad Nacional Autónoma de México. Apartado 70-305, 04510 México, DF, Mexico. 
The identification of species of the Hippolytidae of the Western Atlantic remains a problem to be solved (GORE et al. 1981; VIRSTEIN 1987; HOLMQUIST et al. 1989). The three species of the genus Hippolyte Leach, 1814 registered in Laguna de Términos are Hippolyte curacaoensis Schmitt, 1924, H. pleuracanthus (Stimpson, 1871) and H. zostericola (Smith, 1873) (LEDOYER 1986; BARBA et al. 1993).

Williams (1965) identified H. pleuracantha and $H$. zostericola among the Hippolytidae of the northamerican Atlantic coast. He mentioned the presence of tufts of plumose setae on the carapace of the first species. CHACE (1972) substituted $H$. pleuracantha by $H$. pleuracanthus and $H$. zostericola by $H$. curacaoensis, and at the same time included $H$. zostericola which he took from GURNEY's (1936), $H$. zostericola or H. pleuracantha bermudensis Stimpson, 1871. Later, WooD (1974) still included $H$. pleuracantha and mentioned the presence-absence of tufts of plumose setae on the carapace as a taxonomic characteristic. Lastly, WiLLIAMS (1984) adopted CHACE's (1972) classification and taxonomic criteria, and mentioned the presence of tufts of plumose hairs on the dorsal surface of the carapace and abdomen of $H$. pleuracanthus and $H$. zostericola.

The taxonomic characteristics proposed by CHACE (1972) to distinguish these three species include number of teeth on dorsal margin of rostrum, presence of a strong lateral carina in the proximal third of rostrum, presence of strong distolateral spines on basal segment of the antennular peduncle, and the length of the rostrum with respect to the antennular peduncle. However, some of the characteristics are very variable, for which reason it is still difficult to identify species without problems.

The hypothesis here proposed states that the taxonomic identification of the three species of the genus Hippolyte in Laguna de Términos can be complemented with the colour and the presence-absence of tufts of plumose setae on the carapace and abdomen. This hypothesis would be accepted if the identification based on the taxonomic characteristics proposed by CHACE (1972) were complemented with these features.

Parallel to the analysis of external morphology of the adults, studies on reproductive biology and larval development have been helped in the solution of problems relative to the classification of decapods (FIELDER \& GREENWOOD 1985; RODRIGUES \& HEBLING 1989). This has been focused particularly on those decapods of comercial importance such as penaeid and brachyuran that have been bred extensively (PROVENZANO 1985). To solve the taxonomic problem of $\mathrm{H}$. zostericola and $H$. pleuracanthus, it is considered necessary to analyse the complete larval development of the first species and the geographical distribution of the second (SHIELD 1978).

The purpose of this study is to test the hypothesis through the comparative analysis of the morphology of adult females and of the first larval stage, as well as of the reproductive biology with respect to fecundity and fertility.

\section{STUDY AREA}

Laguna de Términos is the second largest estuarine system of the southwestern Gulf of Mexico (RÁz-Guzman et al. 1986). The lagoon is connected to the 
Sonda de Campeche through the inlets of El Carmen and Puerto Real and receives the input of the rivers Palizada, Chumpán and Candelaria (Fig. 1). The pattern of rainfall establishes a dry season from February to May, a rainy season from June to September and a season of northers from October to January.

The northcentral-northeastern subsystem of the lagoon is characterised by poly-euhaline environments (RÁz-GUZMAN \& DE LA LANZA 1991) with high densities of macrocrustaceans and fish associated with submerged vegetation (VARGAS-MALDONADO et al. 1981; YÁNEZ-ARANCIBIA et al. 1985; RÁZ-GUZMÁN et al. 1986; RÁz-GUZMAN \& SÁNCHEZ 1992). This vegetation is dominated by the seagrass Thalassia testudinum Kon., and to a lower grade by Halodule wrightii Aschers, Syringodium filiforme Kutt. and red algae (RÁZ-GUZMAN \& DE LA LANZA 1991; SÁNCHEZ 1994). Sediment is mostly sandy and silty and sources of organic matter are related to the local submerged vegetation (RÁZ-GUZMAN \& DE LA LANZA 1991).

\section{MATERIAL AND METHODS}

The study was divided into three partial objectives in order to analyse the taxonomic identity of the species of Hippolytidae. The first was directed to the analysis of the morphological characteristics of ovigerous females, the second to the analysis of fecundity and fertility, and the third to the detailed morphological description of the zoeae I.

Ovigerous females of genus Hippolyte were collected during the day in the rainy season. Sampling was carried out on a shoal in the northcentral region of the Términos lagoon (Fig. 1). The Hippolytidae specimens were collected with a Renfro beam net (RENFRO 1962) with a mesh size of $1 \mathrm{~mm}$. The number of trawling operations depended on the abundance of the ovigerous females. The fact that sampling took place in only one season did not affect the objective of the study, as the population structure of this genus is similar throughout the year (BARBA et al. 1993).

The carideans of the three species of the genus Hippolyte in Laguna de Términos were grouped with respect to the external morphological characteristics of colour and tufts of plumose setae. Transparent organisms with tufts of plumose setae on the carapace and abdomen were placed in Group I and green organisms without setae in Group II. After this, a subsample of each group was preserved in alcohol and another was kept alive, in order to try the complete larval development in laboratory.

\section{MORPHOLOGY OF OVIGEROUS FEMALES}

The two groups of Hippolytidae were compared considering the morphological characteristics mentioned by CHACE (1972): (1) the number of teeth on the dorsal margin of the rostrum, (2) the presence of a lateral carina in the proximal third of the rostrum, (3) the presence of distolateral spines on the basal segment of the antennular peduncle, and (4) the length of the rostrum with respect to the antennular peduncle. 

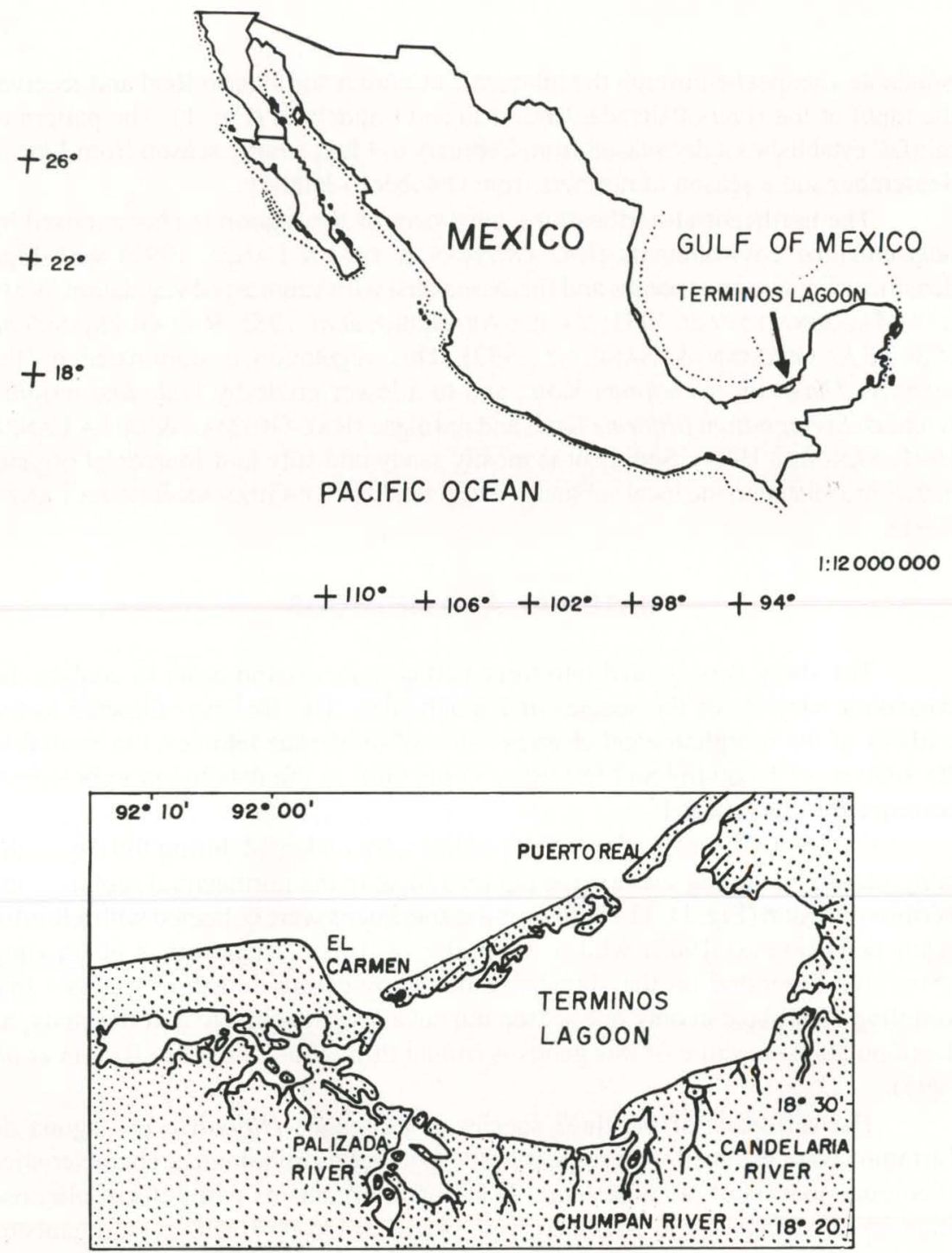

Fig. 1. Terminos lagoon, Mexico.

\section{REPRODUCTIVE BIOLOGY}

\section{Fecundity}

Fecundity has been estimated by direct count of eggs under estereomicroscope (NEGREIROS-FRANSOZO et al. 1992), using volumetric methods (DíAZ et al. 1983 ) or with electronic counters. In this study, fecundity was estimated by counting the number of eggs in the pleopods of each female according to NEGREIROS-FRANsozo et al. (1992); the egg mass were not so big. 
The number of eggs in initial stage of embrionic development, the total cephalothoracic length (TCL), the cephalothoracic length without rostrum (CL) and the weight (W) of 100 ovigerous females of each group were registered.

Average fecundity calculated for groups I and II was compared by Student's $\mathbf{t}$ test (ZAR 1984). The relationship between fecundity and morphometric variables was analysed by simple linear regressions (ETXEBERRIA et al. 1991). The dependent variable was the number of eggs and the independent variables were TCL, CL and $\mathrm{W}$. The slopes of the estimated straight lines for both groups were compared with a covariance analysis (ANCOVA) (SOKAL \& ROHLF 1981).

\section{Fertility}

Live ovigerous females were kept in $70 \mathrm{ml}$ containers with water from the sampling area. Salinity was maintained close to $30 \%$. The fertility of females was calculated using the equation for hatching rate $\mathrm{E}=(\mathbf{L} / \mathbf{H}) \mathbf{1 0 0}$, where $\mathrm{E}=$ hatching rate, $\mathrm{L}=$ average of hatched larvae and $\mathrm{H}=$ average of eggs (LOBÃo et al. 1986). The hatching rate of both groups was compared using a Fisher's $\mathbf{z}$ transformation for independent proportions (LEACH 1982). The average fertility was also calculated for each group by counting the hatched larvae of each female, and was compared using Student's t test (ZAR 1984).

\section{Larval development}

The hatched larvae from 20 females of Group I and six of Group II were kept in containers with water from the sampling locality. Ten live larvae were placed in each container for observation. During the observation period, water in the containers was changed daily and the zoeae were fed with recently hatched nauplii of Artemia salina (Linnaeus, 1758) (NEGREIROS-FrANSOzO et al. 1989; NEGREIROSFRANSOZO \& FRANSOZO 1991).

The detailed description of the zoea I was based on 30 larvae of each group. Zoeae have been placed in the collection of the NEBECC, IB, UNESP, Botucatu (São Paulo), Brazil and in the Laboratorio de Ecología del Bentos, ICMyL, UNAM, México.

\section{RESULTS AND DISCUSSION}

\section{Morphology of adult females}

The presence of 1 to 3 distolateral spines in the basal segment of antennular peduncle was not observed in any species of the Hippolytidae, for which reason the possibility of identifying $H$. curacaoensis was discarded. The absence of $H$. curacaoensis in Laguna de Términos and the numerical dominance of $\mathrm{H}$. zostericola (30,000 specimens) (BARBA et al. 1993$)$ is markedly contrasting with the proportion of these two species registered in Carriacou Island, Lesser Antilles of 1:28 (CHACE 1972) and in seagrass beds of the Veracruz Reef System of 46:1 (HERMOso \& MARTÍNEZ 1991).

Moreover, the rostrum of all females was longer than antennular peduncle, for which reason the species $H$. pleuracanthus is also absent from the samples 
collected in the study area. In the case of the males, however, it is not possible to be sure because length of the rostrum is similar to the antennular peduncle in both $H$. zostericola and $H$. pleuracanthus.

In conclusion, $H$. zostericola is the only species of genus Hippolyte in Laguna de Términos. Thus, groups I and II defined above represent two phenotypes of this species and constitute $66 \%$ and $34 \%$ of the organisms collected, respectively.

\section{Fecundity}

The average number of eggs registered for the Hippolytidae was similar $(p>0.2)$ for both groups (Tab. I).

Table I. Fecundity and fertility of groups I and II of the Hippolytidae in Laguna de Términos. (N) number of specimens females, (TCL) total cephalothoracic length ( $\mathrm{mm}$ ), (CL) cephalothoracic length without rostrum (mm), (W) weight (mg).

\begin{tabular}{ccc}
\hline Hippolytidae & Fecundity & Fertility \\
\hline Group I & $\mathrm{N}=100$ & $\mathrm{~N}=20$ \\
$\mathrm{TCL} 4.83 \pm 0.48$ & $\mathrm{TCL}=4.3 \pm 0.39$ \\
$\mathrm{CL}=2.33 \pm 0.26$ & $\mathrm{CL}=2.1 \pm 0.23$ \\
$\mathrm{~W} 20.48 \pm 7.69$ & \# Zoeae $=87.9 \pm 28.13$ \\
& \# eggs $=103.83 \pm 37.09$ & Hatching rate $=91.5 \%$ \\
& $\mathrm{~N}=100$ & $\mathrm{~N}=6$ \\
$\mathrm{TCL} 4.91 \pm 0.56$ & $\mathrm{TCL}=4.6 \pm 0.59$ \\
$\mathrm{CL}=2.42 \pm 0.26$ & $\mathrm{CL}=2.3 \pm 0.22$ \\
$\mathrm{~W}=21.39 \pm 7.85$ & \# Zoeae $=84.5 \pm 31.4$ \\
& \# eggs=103.83 \pm 41.07 & Hatching rate $=81.5 \%$ \\
\hline
\end{tabular}

*. Fertility and fecundity: $0.5>p>0.2$; hatching rate: $p>0.5$.

On the other hand, the slopes of the estimated straight lines for the linear regression between the fecundity and the TCL, CL and W of those two groups were homogeneous (Tab. II). The slopes of the two straight lines were not significantly different $(\mathrm{p}>0.05)$. This confirms the conclusion that both groups belong to the same species.

Table II. Analysis of covariance between Group I and Group II with respect to fecundity and the morphometric variables. (F ratio) Statistical test result, $(P)$ Probability.

\begin{tabular}{lcc}
\hline \multicolumn{1}{c}{ Source } & F ratio & $P$ \\
\hline Group $\mathrm{CL}$ & 0.183 & 0.669 \\
Group $\mathrm{TCL}$ & 0.012 & 0.914 \\
Group Weight & 0.451 & 0.503
\end{tabular}

*. (CL) Cephalothorax lenght, (TCL) total cephalothorax lenght, (Weight) individual lenght.

The regression analysis between fecundity and the morphometric variables of the two groups resulted in a direct linear relationship $(p<0.05)$ in such a way that at greater TCL, CL and W, number of eggs increased (Tab. III). This fact evidences mainly to two factors: (1) a mechanical one, considering that a greater area within 
the pleopods of bigger females lets them keep a greater number of eggs, and (2) a physiological one that refers to the fact that bigger females can invest a greater quantity of energy towards the production of eggs. Previous studies on crabs (HINES 1982, 1988) have described a linear or logarithmical relationship between the number of eggs and the cube of the cephalothorax length, because he assumed that the amount of eggs is associated to the internal volume of the crustacean body . However, variations have been registered for this relationship with respect to the location (PARSONS \& TUCKER 1986) and the size of the organisms (NEGREIROSFRANSOZO et al. 1992).

Table III. Linear relationship between fecundity and the morphometric variables of cephalothoracic length $(\mathrm{mm})$ and weight $(\mathrm{mg})$ for groups I and II. (F ratio) Statistical test result, (P) Probability (Highly significant difference $p<0.001$ ).

\begin{tabular}{|c|c|c|}
\hline Source & F ratio & $\mathrm{P}$ \\
\hline$C L$ & 134.880 & 0.000 \\
\hline TCL & 137.984 & 0.000 \\
\hline Weight & 142.252 & 0.000 \\
\hline
\end{tabular}

*. (CL) Cephalothorax lenght, (TCL) total cephalothorax lenght, (Weight) individual lenght.

\section{Fertility}

As in the case of fecundity, the average number of larvae in the stage of zoea I registered was similar $(0.5>p>0.2)$ for groups I and II (Tab. I).

The hatching rates calculated for group I (91.5\%) and group II (81.5\%) were significantly similar $(\mathrm{p}>0.05)$. These hatching rates are considered high compared with those registered for the carideans of the genus Macrobrachium Bate, 1888, for which the rates are lower than 50\% (LoBÃo et al. 1986).

Larvae of the ovigerous females hatched in the laboratory after one or two days. After three or four days some females suffer ecdysis and spawned again. Such a continuous reproduction has been registered for several species of carideans in tropical latitudes including Hippolyte curacaoensis, Thor manningi Chace, 1872, Leander tenuicornis (Say, 1818), Latreutes fucorum (Fabricius, 1798), Latreutes parvulus (Stimpson, 1866), Periclimenes americanus (Kingsley, 1878), Processa bermudensis (Rankin, 1900), Processa riveroi Manning \& Chace, 1971 and Alpheus normanni Kingsley, 1878 (DUGAN 1983; BAUER 1989). This kind of reproduction with succesive spawnings is the result of type of strategy called " $r$ " in the life cycle of the carideans (BAUER 1989).

\section{Description of the first zoea}

The stage I of groups I and II are similar having an anteroposteriorly elongated carapace with four to five spines on the anterolateral margin; eyes sessiles; abdomen with five segments and $6^{\text {th }}$ somite joined to the telson, bearing a pair of posterolateral spines; telson bears a pair of posterolateral plumose spines and six distal pairs of plumose setae; antenna with unisegmented base, antennal scale and antennal flagellum, bigger than antennal scale bearing small setules and the scale 10 plumose setae (Fig. 2). 


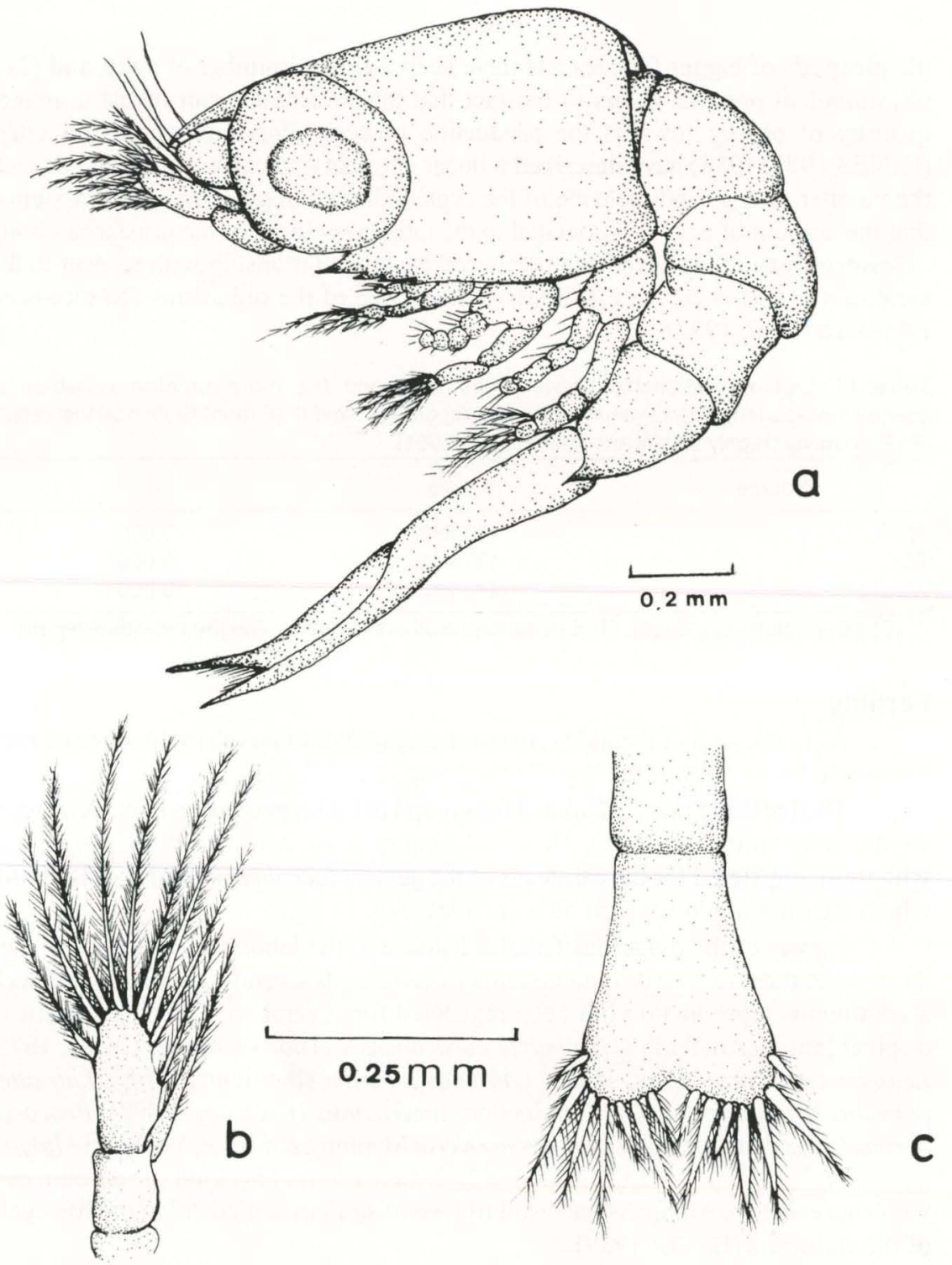

Fig. 2. Hippolyte zostericola first zoeal stage. (a) Lateral view; (b) antenna, (c) telso.

External morphology of the zoea I of groups I and II are similar to the zoea I of the H. pleuracanthus described by SHIELD (1978), but number of anterolateral spines of the carapace are bear four and five spines in the groups I and II and the zoea of $H$. pleuracanthus only two spines (SHIELD 1978) (Tab. IV). This excludes the species $H$. pleuracanthus from the zoeae that were analysed and coincides with the conclusion reached from the morphometric analysis of the adult females. 
With respect to studies on larval development, GURNEY (1936) described four larval stages and two postlarvae for $H$. pleuracantha bermudensis Stimpson, 1871 named by CHACE (1972) as H. zostericola. However, the larval stage described by GURNEY (1936) as zoea I is actually a later stage because of the presence of first pereiopod which is normally present only in the last decapods zoeal stages. The zoea I described here did not have the rudiments of the first pereiopod.

Table IV. Morphological comparison of the first zoeal stage of the carideans from Group I, Group II ( present study) and Hippolyte pleuracanthus studied by SHIELD (1978).

\begin{tabular}{|c|c|c|c|}
\hline Structures & Group I & Group II & H. pleuracanthus \\
\hline CARAPACE & 4-5 antero-lateral spines & 5 antero-lateral spines & 2 antero-lateral spines \\
\hline \multicolumn{4}{|l|}{ ANTENNULE } \\
\hline Antennular flagellum & $\begin{array}{l}2 \text { aesthetascs and } 1 \text { simple } \\
\text { setae }\end{array}$ & $\begin{array}{l}2 \text { aesthetascs, } 1 \text { spine and } 2 \\
\text { simple setae }\end{array}$ & $\begin{array}{l}2 \text { aesthetascs and } 1-2 \text { simple } \\
\text { setae }\end{array}$ \\
\hline \multicolumn{4}{|l|}{ MAXILULE } \\
\hline Endopod & 4 plumose spines & 4 plumose spines & 5 setae \\
\hline Basal endite & $4-5$ spines & 6 spines & 5 triangular teeth \\
\hline Coxal endite & $\begin{array}{l}5 \text { plumose spines and } \\
1-2 \text { plumose setae }\end{array}$ & $\begin{array}{l}5 \text { plumose spines and } \\
1 \text { plumose setae }\end{array}$ & 5 and 1 setae \\
\hline \multicolumn{4}{|l|}{ MAXILLA } \\
\hline \multicolumn{4}{|l|}{ Coxal endite } \\
\hline proximal lobe & 5-6 plumose setae & 5 plumose setae & 8 setae \\
\hline distal lobe & 2 plumose setae & 3 plumose setae & 3 setae \\
\hline \multicolumn{4}{|l|}{ Basal endite } \\
\hline proximal lobe & 3 plumose setae & 5 plumose setae & 4 and 3 setae \\
\hline distal lobe & 3 plumose setae & 5 plumose setae & 3 and 1 setae \\
\hline Scaphognatite & 5 plumose setae & 5 plumose setae & 5 plumose setae \\
\hline \multicolumn{4}{|l|}{ FIRST MAXILLIPED } \\
\hline Coxopod & 3 plumose setae & 2 plumose setae & 4 plumose setae \\
\hline Basipod & 10 plumose setae & 10 plumose setae & 11 plumose setae \\
\hline Endopod & $3,1,2$ and 4 plumose setae & $3,1,2$ and $3-4$ plumose setae & $3,1,2$ and 4 plumose setae \\
\hline Exopod & 0,1 and 3 plumose setae & 0,1 and 3 plumose setae & 0,1 and 4 plumose setae \\
\hline \multicolumn{4}{|l|}{ SECOND MAXILLIPED } \\
\hline Coxopod & 1 plumose setae & 0 & 1 plumose setae \\
\hline Basipod & 10 plumose setae & 6 plumose setae & 8 and 1 plumose setae \\
\hline Endopod & 3,13 and 3 plumose setae & $2,1,2$ and 3 plumose setae & $3,2,4-3$ and 5 plumose setae \\
\hline Exopod & 0,1 and 4 plumose setae & 0,2 and 3 plumose setae & $0,0,2$ and 4 plumose setae \\
\hline \multicolumn{4}{|l|}{ FIRST MAXILLIPED } \\
\hline Coxopod & 0 & 0 & 0 \\
\hline Basipod & 1 plumose setae & 2 plumose setae & 2 setae \\
\hline Endopod & $1,1,3$ and 3 plumose setae & $3,1,2$ and 3 plumose setae & $1,0,2$ and 4 plumose setae \\
\hline Exopod & $0,0,1$ and 3 plumose setae & $0,0,2$ and 3 plumose setae & $0,0,2$ and 3 plumose setae \\
\hline
\end{tabular}

\section{CONCLUSIONS}

The results obtained from the analysis of the external morphology, the fecundity and the fertility of adult females, as well as of the zoeae I, it is possible to establish that(1) the females and the zoeae I of groups I and II belong to $H$. zostericola, and (2) the species presents two phenotypes, one of transparent organisms with tufts of plumose setae and another of green organisms without tufts of plumose setae. The phenotypical variation of $H$. zotericola can be the result of the use of the microhabitat of this species with respect to its diet. Similarly, EwALD (1969) registered a direct relationship between the colour of the arrow shrimp Tozeuma carolinense Kingsley, 1878 and its diet. 
The hypothesis was not accepted as the taxonomic identification was not complemented by the external characteristics of colour and tufts of plumose hairs on the carapace and abdomen. For the same reason, it can be established that such characteristics have no taxonomic value as WOOD (1974) had proposed. WILLIAMS (1984) later mentioned this characteristic in description of $H$. pleuracanthus and $H$. zostericola, and now specimens of $H$. zostericola have been identified without tufts of plumose setae on the carapace and abdomen.

ACKNOWLEDGEMENTS. The authors are grateful to L.A. Soto, head of the Lab. Ecología del Bentos for his overall support, to F. Vera, A. Ortega and A. Reda, of the field station of El Carmen-ICMyL for their help at the station and on the lagoon, and to N. Cann's for helping to review the specimens. This study was financed by the research project "Interacciones Ecológicas en Comunidades Bénticas Litorales/OGMEX-Comunidades Bénticas" of the ICMyL, UNAM, and was carried out during a short stay of the members of the NEBECC in Mexico. The authors are gratefull to Pillar Peralta-Pereira, to Rosa Florido-Araújo y Patricia Schmidtsdorf for their helping during the field work.

\section{REFERENCES}

Barba, E.M., A. RAz-GuzMan \& A.J. SANCHEZ. 1993. Patrones de distribución de los carideos de Laguna Madre, Tamaulipas y Laguna de Términos, Campeche. In: XII Congreso Nacional de Zoología. Monterrey, Nuevo León, México, p.43-44.

BAUER, R.T. 1989. Continuous reproduction and episodic recruitment in nine shrimp species inhabiting a tropical seagrass meadow. J. Exp. Mar. Biol. Ecol. 127: $175-187$.

ChACE JR., F.A. 1972. The shrimps of the Smithsonian-Bredin Caribbean expeditions with a summary of the West Indian shallow-water species (Crustacea, Decapoda, Natantia). Smithsonian Contributions to Zoology 98: $\mathrm{i}-\mathrm{x}, 1-179$.

DAY, J.W.; R.H. DAY; M.T. BARREIRO; F. LeY-Lou \& C.J. MAdDEN.1982. Primary production in the Laguna de Términos, a tropical estuary in the southern Gulf of Mexico. Oceanol. Acta, São Paulo: 269-276.

Diaz, H.; J.E. Conde \& M. BevilacQua. 1983. A volumetric method for estimating fecundity in Decapoda. Mar. Ecol. Prog. Ser. 10: 203-206.

DUGAN, P.J. 1983. Seasonal and geographic distribution of seven decapod crustaceans in Apalachee Bay, Florida. Contrib. Mar. Sci. 26: 65-79.

ETXEBERRIA, J.; L. JOARISTI \& L. LizASOAIN. 1991. Programación y análisis estadísticos básicos con SPSS/PC+. Madrid, Ed. Paraninfo, 337p.

EWALD, J.J. 1969. Observations on the biology of Tozeuma carolinense (Decapoda, Hippolytidae) from Florida, with special reference to larval development. Bull. Mar. Sci. 19 (3): 510-549.

Fielder, D.R. \& J.G. GreEnwood. 1985. The systematic position of Heloecius cordiformis (H. Milne Edwards, 1837) (Decapoda, Ocypodidae) as revealed by larval morphology. Crustaceana 48 (3): 244-248. 
Gore, R.H.; E.E. Gallagher; L.E. ScotTo \& K.W. Wilson. 1981. Studies on decapod crustacea from the Indian River region of Florida. XI. Community composition, structure, biomass and species-areal relationships of seagrass and drift algae-associated macrocrustaceans. Est. Coast. Shelf. Sci. 12: 485-508.

GuRnEY, R. 1936. Notes on some decapod crustaceans of Bermuda. II. The species of Hippolyte and their larvae. Proc. zool. Soc. London: 1-9.

HINES, A.H. 1982. Allometric constraunts and variables of reproductive effort in Brachyuran crabs. Mar. Biol. 69: 309-320.

1988. Fecundity and reproductive output in two species of deep-sea crabs, Geryon fenneri and Geryon quinquedens (Decapoda: Brachyura). J. Crust. Biol. 8 (4): 557-562.

Holmquist, J.F.; G.V.N. Powell \& S.M. Sogard. 1989. Decapod and stomatopod communities of seagrass-covered mud banks in Florida Bay: Interand intra-bank heterogeneity, its special reference to isolated subenvironments. Bull. Mar. Sci. 44: 251-262.

Hermoso, A.M. \& L.A. MARTinez. 1991. Estudio taxónomico de ocho familias de camarones (Crustacea: Decapoda) en cinco arrecifes en el Golfo de México. Tesis profesional, not publicated, Facultad de Ciencias, UNAM, México, DF, 87p.

LEACH, C. 1982. Fundamentos de estadística: enfoque no paramétrico para ciencias sociales. Mexico, Ed. Limusa, 422p.

LEDOYER, M. 1986. Faune mobile des herbiers de phanérogames marines (Halodule et Thalassia) de la Laguna de Términos (Mexique, Campeche) I. Les caridea (Crustacea: Decapoda) et aperçu sur la faune globale. An. Inst. Biol. Univ. Nal. Autón. México 13 (3): 147-170.

LoBÃo, V.L.; N.E.T. Rojas \& W.C. VALENTI. 1986. Fecundidade e fertilidade de Macrobrachium amazonicum (Heller, 1862) (Crustacea, Decapoda) em laboratorio. Bol. Inst. Pesca 13 (2): 15-20.

Negreiros-Fransozo, M.L. \& A. Fransozo. 1991. Larval stages of Epialtus brasiliensis Dana, 1852 (Decapoda, Brachyura, Majidae) reared in the laboratory, with notes on characters of the majid subfamilies. Crustaceana 60 (2): 200-212.

Negreiros-Fransozo, M.L.; A. Fransozo; F.L.M. Mantelatto; J.M. NAKAGAKi \& M.C.F. SPILborghs. 1992. Fecundity of Paguristes tortugae Schmitt, 1933" (Crustacea, Decapoda, Anomura) in Ubatuba (SP), Brazil. Rev. Brasil. Biol. 52 (4): 547-553.

Negreiros-Fransozo, M.L.; A. Fransozo \& N.J. Hebling. 1989. Larval development of Persephona mediterranea (Herbst, 1794) (Brachyura, Leucosiidae) under laboratory conditions. Crustaceana 57 (2): 177-193.

PARSONS, D.G. \& G.E. TUCKER. 1986. Fecundity of northern shrimp, Pandalus borealis, (Crustacea, Decapoda) in areas of the Northwest Atlantic. Fish. Bull. 84 (3): 549-558.

Provenzano JR., A.J. 1985. The Biology of Crustacea: Economic Aspects:

Fisheries and Culture. New York, Academic Press Inc., vol. 10, XXV+331p. 
RÁz-Guzman, A. \& A.J. SANCHEZ. 1992. Registros adicionales de cangrejos braquiuros (Crustacea: Brachyura) de Laguna de Términos Campeche. An. Inst.

Biol. Univ. Nal. Autón. México, Ser. Zool. 63 (1): 29-45.

Ráz-Guzman, A.; A.J. Sanchez; L.A. Soto \& F. Alvarez. 1986. Catálogo ilustrado de cangrejos braquiuros y anomuros de Laguna de Términos, Campeche (Crustacea: Brachyura, Anomura). An. Inst. Biol. Univ. Nal. Autón. México, Ser. Zool. 57 (2): 343-383.

RÁZ-GUZMAN, A. \& G. DE LA LANZA. 1991. Evaluation of photosynthetic pathways of vegetation, and of sources of sedimentary organic matter through $\mathrm{d}^{13} \mathrm{C}$ in Terminos Lagoon, Campeche, Mexico. An. Inst. Biol. Univ. Nal. Autón. México, Ser. Bot., 62 (1): 39-63.

RENFRO, W.C. 1962. Small beam net for sampling postlarval shrimp. US Fish. Wildl. Serv. Circ. 161: 86-87.

Rodrigues, M.D. \& N.J. Hebling. 1989. Ucides cordatus cordatus (Linnaeus, 1763) (Crustacea, Decapoda). Complete larval development under laboratory conditions and its systematic position. Revta bras. Zool. 6 (1): 147-166.

SANCHEZ, A.J. 1994. Feeding habits of Lutjanus apodus (Osteichthyes: Lutjanidae) in Laguna de Términos, southwest Gulf of Mexico. Rev. Inv. Mar. 15 (2): 125-134.

SANCHEZ, A.J.\& A. RÁz-GUZMAN. 1992. Distribution patterns of aquatic brachyuran crabs (Crustacea: Decapoda) in a tropical estuarine system: Terminos Lagoon, southern Gulf of Mexico. British Ecological Society \& ASLO Symposium, "Aquatic Ecology: Scale, Pattern \& Process". Cork, Ireland.

SHIELD, P.D. 1978. Larval development of the caridean shrimp, Hippolyte pleuracanthus (Stimpson) reared in the laboratory. Estuaries 1 (1): 1-16.

SoKal, R.R. \& F.J. RoHLF. 1981. Biometry. San Francisco, W.H. Freeman and Co., 859p.

VARGAS-MALDONADO, I.; A. YAÑEZ-ARANCIBIA \& F. AMEZCUA-LiNARES. 1981. Ecología y estructura de las comunidades de peces en areas de Rhizophora mangle y Thalassia testudinum de la Isla del Carmen, Laguna de Términos, sur del Golfo de México. An. Inst. Cienc. del Mar y Limnol. Univ. Nal. Autón. México 8 (1): 241-266.

VIRNSTEIN, R.W. 1987. Seagrass-associated invertebrate communities of the southeastern USA: A Review. Fla. Mar. Res. Publ. 42: 89-116.

Williams, A.B. 1965. Marine decapod crustaceans of the Carolines. US Fish. Wildl. Serv. Fish. Bull. 65 (1): 1-298.

1984. Shrimps, Lobsters, and Crabs of the Atlantic Coast of the Eastern United States, Maine to Florida. Washington, Smithsonian Institution Press, 550p.

WooD, C.E. 1974. Key to the Natantia (Crustacea, Decapoda) of the coastal waters of the Texas Coast. Contrib. Mar. Sci. 18: 35-56.

Yañez-Arancibia, A.; A.L. Lara-Dominguez; A. Aguirre-Leon; F. Amezcua-Linares; D. Flores-Hernandez \& P. Chavance. 1985. Ecology 
of dominant fish populations in tropical estuaries, environmental factors regulating biological strategies and production, p.311-367. In: A. YÁÑEZ-ARANCIBIA (Ed.). Fish Community Ecology and Coastal Lagoons: Towards an Ecosystem Integration. Mexico, Editorial Universitaria, UNAMPUAL-ICMyL, 654p.

ZAR, J.H. 1984. Biostatistical Analysis. Prentice-Hall Inc. New Jersey, 718p.

Recebido em 30.XI.1995; aceito em 21.X.1996. 